\title{
Person With Disabilitities Protection Prospects Against Discriminatory Behavior
}

\author{
Lita Tyesta ALW \\ Faculty of Law \\ Universitas Diponegoro \\ Semarang, Indonesia \\ litatyestalita@yahoo.com
}

\begin{abstract}
This research aimed to determine the prospects of persons with disabilities protection against discriminatory behavior in Semarang. The research method is normative and empirical legal research using the laws approach (statutory approach), and the conceptual approach. Results of the study found that the government of Semarang have prospects in providing protection and fulfillment of the rights of persons with diasabilitas of discriminatory behavior. Constitution of the Republic of Indonesia Year 1945 does not set a specific reference on Disability, but set firmly and clearly regarding non-discrimination, equality before the law, and the right to receive equal treatment before the law throughout Indonesia.
\end{abstract}

Keywords - Protection, person with disabilities, discriminatory behavior.

\section{INTRODUCTION}

Pancasila and the Constitution of the Republic of Indonesia Year 1945 respecting and upholding human dignity, including the human rights of all citizens. Similarly, the Persons with Disabilities as part of Indonesian citizens also should get equal treatment to be respected, upheld the dignity and the protection and fulfillment of their human rights as stipulated in Law No. 39 Year 1999 on Human Rights The fact until today, in the midst of society still found behavior that does not support the existence of the Persons with Disabilities with various assumptions/stereotypes, among others, that the disability is an object to be pitied because of exceptional/special, can not to be independent, cumbersome, must always assisted, difficult to adapt, and should subjected to charity and alms.

Besides the physical condition of the Persons with Disabilities considered sick, should be treated, must be treated with extra effort, unable to care for or care for children and asexual. Its existence is considered shameful, to be ostracized, and better stay at home. When he was about to follow the education of disability regarded as an exclusive individual and should be educated in schools (SLB)/Special School, only to have the skills are limited as a tailor, masseur and a telephone operator and does not have the capability to get a job in the formal sector (clerk/PNS) [1]. In the legal field, because of his disability, they are considered unable to testify before the law and actions may be considered null and void. Not infrequently, they often encountered culture that assumes that a Person with Disabilities is a sinner, the carrier of disgrace, due to the sin committed by the parents or family. The views and attitudes of behavior as mentioned above is a form of discrimination which violate the dignity and worth inherent in the Person with Disabilities.

The Government of the Republic of Indonesia, has actually also set various laws which substantially ensures the protection efforts in order to fulfill the rights of Persons with Disabilities, of which set in over 7 laws and regulations. However, the setting-regulation is only partially dispersed in various Ministries/Work Units (SKPD) and still weak in implementation.

Government of Semarang of Central Java Province as part of the Republic of Indonesia, is committed to carry out the mandate of Pancasila and the Constitution of the Republic of Indonesia Year 1945 in an effort to improve the welfare of the people of the city of Semarang, including the Person with Disabilities through various policies and programs which the application is scattered in various regulations area, as contained in the regional Semarang Long Term Development Plan 2005-2025.

It is the duty of Semarang City Government for the realization of the rights contained in Law No. 19 Year 2011 on Ratification of the Convention on the Rights of Persons with Disabilities (CRPD), through the local legislation which would integrate various legal provisions to ensure the implementation of participation and fulfillment of the rights of persons with disabilities in all aspects of life [2]. In addition, the Central Java Provincial Government has also imposed Provision Central Java Regional Regulation No. 11 Year 2014 About Fulfilling the Rights of Persons with Disabilities. Thus, the mandate of the Act and the Provincial Regulation should be immediately followed by Semarang City.

\section{RESEARCH METHODS}

Research conducted in the preparation of this academic paper using normative juridical method that focuses on the study of legal norms contained in legislation on disability, namely the various laws and regulations that directly or indirectly related to the disability. This research was conducted with several methods of approach, namely: Legislation approach (statute approach); used to examine 
and analyze a wide range of legislation governing disability. A conceptual approach; used to explore the concept of disability in the law system of Indonesia. Based on these conclusions, this study looked at the need to provide recommendations that should be set into the Draft of Regional Regulation of Semarang on Fulfillment of the Rights of Persons with Disabilities as a solution to overcome the problems with Disabilities in Semarang.

\section{RESULT FINDINGS AND DISCUSSION}

United Nations Convention on Rights of Persons with Disabilities (CRPD) which is commonly referred to as "the Convention of Disabilities" states that man is unique and serves as a development tool at the same time also as human rights instruments. In addition, this document also legally binding force cross-disability and cross-sector. the purpose of the Convention on disability, as stated in article 1 , is to "promote, protect and ensure that all persons with disabilities enjoy their rights fully and equitably, and to uphold respect for their dignity"[3]. The Convention regulates the various aspects and sectors related to the rights of persons with disabilities and how to adopt these principles into legislation and action. Those, any country that ratified the CRPD obliged to adopt this Convention in the legislation national and local levels.

With the Law No. 19 of 2011, hence the use of the term people with disabilities which has been used should be replaced by persons with disabilities. The term "disabled" used is no longer desired for the following reasons. At the international level, the United Nations Convention on the Rights of Persons with Disabilities (UNCRPD), defines persons with disabilities as, those who have long-term physical, mental, intellectual or sensory impairments the which in interaction with various barriers may hinder their full and effective participation in society on an equal basis with others. They are those who have physical limitations, mental, intellectual or sensory impairments in the long term when dealing with various obstacles, it may hinder their full and effective participation in society on an equal basis with others.

From the description above shows that the definition of disability is still very diverse because of the nature of disability itself are complex, dynamic, multidimensional, and diverse. In recent decades the movement of persons with disabilities, including a variety of research in the field of social and health, has been able to identify the physical and social role in relation to disability. The shift from a medical perspective towards structural perspective, the social can be termed as a shift from a medical model towards the social model where disability is viewed from the side of the people than the physical side.
Medical model and the social model is often presented as dichotomous, but disability can not solely be viewed purely medical or social. A balanced approach is needed related to many aspects of disability. To that end, the World Health Organization (WHO) has published the International Classification of Functioning, Disability and Health (ICF). ICF emphasizes the environmental factors that cause disability. Disability refers to the emergence of difficulties in all three of the above. Disability arises from the interaction of health conditions and environmental factors and personal as illustrated in the following chart.

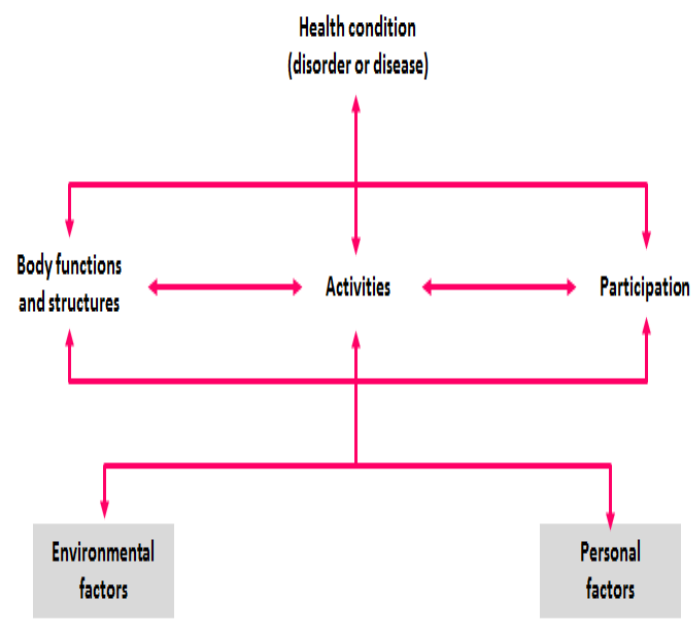

Chart representation of ICF, Disability and Health (Source: World Health Organization, World Report on Disability, 2011)

Ministry of Social Affairs estimates that the population of disabled in Indonesia are at $3.11 \%$, according to data from the Ministry of Health put the figure in excess of $6 \%$, while the number of handicapped WHO conveying of developing countries at $10 \%$. To know the real population of persons with disabilities in Indonesia is not easy, this is due to the weakness of the data collection system on population in Indonesia. Data with disabilities nationally issued by BPS is based on the results SUSENAS 2009 using categorization of disability, such as Law No. 4 Year 1997.

The statistics are presented in the form that says "Yes" in the countryside (1,198,185 inhabitants), urban (928,600 inhabitants), and total (2,126,785 inhabitants). Data Population with disabilities in Central Java based on data collected by Social Service of Central Java Province in December 2012 amounted to 237,400 people, these data are not data on the whole population of persons with disabilities, but the data that is with social welfare problems (PMKS/ Penyandang Masalah Kesejahteraan Sosial). The data is used as reference in formulating policy / management programs for persons with disabilities in Central Java. 
Fulfillment of the rights of Persons with Disabilities basically has generally been stipulated in the Constitution of the Republic of Indonesia Year 1945 and Law No. 39 Year 1999 on Human Rights, and specifically governed by Law No. 4 Year 1997 on Persons with Disabilities, as well as Government Regulation No. 43 Year 1998 On Measures to Improve Social Welfare of Persons with Disabilities. Constitution of the Republic of Indonesia Year 1945 did not set a specific reference on disability, but set firmly and clearly regarding non-discrimination, equality before the law, and the right to receive equal treatment before the law.

Regional Government of Semarang have prospecting arrangements for the protection of persons with disabilities up to the present time has not been set up to fulfill the rights of Persons with Disabilities issues in a regional regulation. Local Regulation that has been established and has been enacted is the Central Java Provincial Regulation on Fulfilling the Rights of Persons with Disabilities.
[1] Suryandaru SH SS, Chairman of Persons With Disabilities Pertuni Central Java, An alumnus of the Australian Leadership Awards 2012, students of the Master Program Institute on Disability and Public Policy at the American University in the article "On Welcoming The Birth of Disabilities Regulation" in the newspaper "Suara Merdeka"

[2] Mallett, Rebecca and Katherine Runswick-Cole, Aproaching Disabilities, Critical issues and perspectives, Routledge, New York, 2014.

[3] Lili Rasidi, Philosophy of Law, What is Law ?, PT. Remaja Rosdakarya Bandung, 1993.

[4] Satjipto, Rahardjo, Legal Studies, PT. Citra Aditya Bakti, Bandung, 1991

[5] Mertokusumo, Sudikno, Understanding Law, An Introduction, Liberty Yogyakarta, 1986 